\title{
Analysis of Tools to Evaluate Chloride Threshold for Corrosion Onset of Reinforced Concrete in Tropical Marine Environment of Yucatán, México
}

\author{
Pedro Castro-Borges, Mercedes Balancán-Zapata, and Alexander López-González \\ Centro de Investigación y de Estudios Avanzados, IPN, Km. 6 Ant. Carr. a Progreso, 97310 Mérida, Unidad Mérida, YUC, Mexico \\ Correspondence should be addressed to Pedro Castro-Borges; pcastro@mda.cinvestav.mx
}

Received 29 June 2012; Revised 8 September 2012; Accepted 16 September 2012

Academic Editor: Guillaume Galliero

Copyright (C) 2013 Pedro Castro-Borges et al. This is an open access article distributed under the Creative Commons Attribution License, which permits unrestricted use, distribution, and reproduction in any medium, provided the original work is properly cited.

\begin{abstract}
The chloride threshold for corrosion onset of reinforced concrete depends on several factors and is only valid for the specific condition of each factor. The main objective of this paper was to analyze different tools to obtain the chloride threshold for corrosion onset of reinforced concrete in tropical marine environment. Sixty Portland cement concrete cylinders were exposed in a tropical marine environment. One half of the samples had a reinforcing bar embedded at the center of the sample (corrosion measurements), and the other half was made with plain concrete (chloride measurements). Five water/cement ratios were tested representing the common practices of this region. The corrosion rate was monitored using the polarization resistance technique, and the chloride content was determined using an ion selective electrode. The chloride threshold was in the range of $0.3 \%$ to $1.1 \%$ by weight of cement for specimens at $50 \mathrm{~m}$ from the seashore. Main conclusion indicates that $i_{\text {accum }}$ is a better tool to determine and/or predict chloride threshold in this study according to a conservative point of view in civil engineering. Using this tool, chloride threshold was $0.26 \%$ to $0.73 \%$ by weight of cement.
\end{abstract}

\section{Introduction}

Concrete mix proportions, $\mathrm{pH}$ of pore solution [1], moisture content in the concrete [2], temperature, type of cation, $\mathrm{C}_{3} \mathrm{~A}$ content of cement [3], proportion of soluble chloride [4], and blended materials are some of the variables that can cause differences in the reported chloride thresholds. Another variable is the way depassivation is detected $[5,6]$. Data from several authors on field and laboratory studies of mortar and concrete have shown that total chloride thresholds can vary by more than one order of magnitude $(0.15 \%$ to $2.5 \%)$ [7]. However, in spite of the interesting findings of the different authors, there is still not enough reported chloride thresholds for concretes exposed to tropical marine environment. In this paper, as in other works [5], chloride thresholds are identified by measuring the corrosion rate using the polarization resistance technique and presents an analysis of the results using instantaneous icorr $\left(i_{\text {corr }}\right)$, mean icorr $\left(i_{\text {mean }}\right)$, and accumulated icorr $\left(i_{\text {accum }}\right)$, finding differences in the threshold depending on the tool used.
The main objective is to discuss $i_{\text {corr }}, i_{\text {mean }}$, and $i_{\text {accum }}$ as practical tools to determine chloride thresholds for Portland cement reinforced concrete exposed to a tropical-marine environment.

\section{Experimental Procedure}

Sixty Portland cement concrete cylinders $(\sim 75 \times 150 \mathrm{~mm})$ were exposed to a tropical marine microclimate $(50 \mathrm{~m}$ from the seashore) for a period of more than five years. One-half of the samples had a \#3 (ASTM) reinforcing bar embedded in the concrete (corrosion measurements), and the other half was made with plain concrete (chloride measurements). Five water/cement $(\mathrm{w} / \mathrm{c})$ ratios $(0.46,0.53,0.59,0.70$, and 0.76$)$ and three times (tc) of curing (1, 3 and 7 days) were tested representing common compressive strength used in this region. The samples were prepared using crushed limestone aggregates. Six cylinders represented each $\mathrm{w} / \mathrm{c}$ ratio (2 per tc), and the average of their measurements is represented in the 

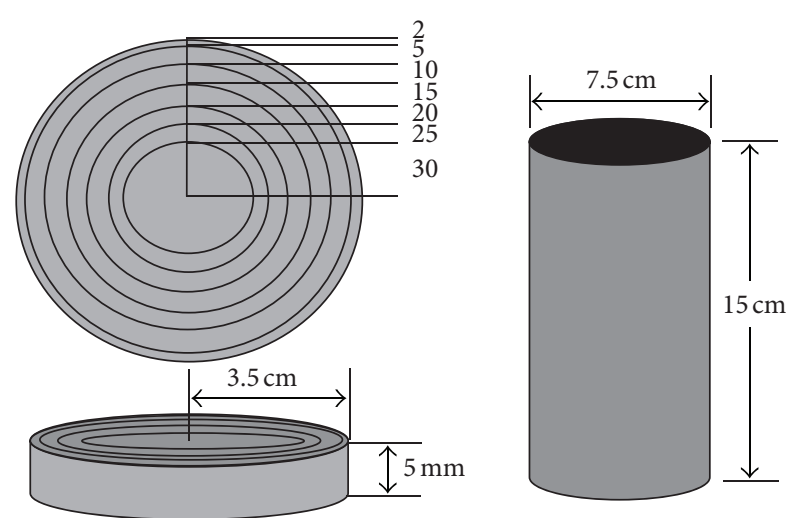

FIGURE 1: Sketch of specimens used to extract and determine chlorides.

following applicable figures and tables. The cylinders were sealed in their top and bottom faces with epoxy coatings in order to allow the entrance of chloride in the radial direction only.

A $5 \mathrm{~mm}$ diameter slice was cut from the unreinforced samples prior to the exposure and at 6, 12, 24, and 45 months. Powders were obtained at several depths from the slice with a drill in order to obtain the total chloride content (Figure 1) which was determined through an ion-selective electrode. Details about the extraction and determination method can be observed in [8].

The reinforcing steel was $9.5 \mathrm{~mm}$ in diameter and was treated before casting by weighing it as received from the factory. An epoxy coating and tape were applied to limit the area of study and to isolate the exposed steel surface. Between the concrete and the steel bar surface, and exactly at the middle of the rebar, an activated titanium rod (ATR) was positioned to serve as the reference electrode (RE) during the corrosion measurements. The ATR was continuously calibrated against a saturated calomel electrode (SCE) as was previously characterized [9]. The counter electrode (CE) was a single $15 \mathrm{~mm}$ ( $0.6 \mathrm{inch})$ wide strip of conductive elastomer (resistivity $\sim 1 \Omega \cdot \mathrm{cm}$ ) running along the entire exposed concrete length. The strip was pressed longitudinally on the concrete surface using a stiff contoured metal bar that was fastened easily to the cylinder by two worm-thread hose clamps. Plastic ribbon spacers prevented the metal clamps from electric contact with the concrete surface [10]. A sketch of the specimen has been published in several works $[7,8,10]$ and it is showed with the cell configuration in Figure 2. The stiffener bar was used to force a good contact between the conductive elastomer and the concrete surface. The instantaneous corrosion rate $\left(i_{\text {corr }}\right)$ was monitored using the polarization resistance technique at a scan rate of $0.06 \mathrm{mV} / \mathrm{s}$. More details about the experimental procedure have been published elsewhere [8]. Mix proportions are given in Table 1.

The criterion for considering the rebar as depassivated was a corrosion rate between 0.1 and $0.2 \mu \mathrm{A} / \mathrm{cm}^{2}$ [11]. A chloride content analysis was done prior to the exposure and at $6,12,24$, and 45 months of exposure. The mean corrosion rate $\left(i_{\text {mean }}\right)$, as in other works [5], was obtained
TABle 1: Mix proportions.

\begin{tabular}{ccccc}
\hline \multirow{2}{*}{ w/c } & \multicolumn{4}{c}{ Mix proportions $\left(\mathrm{Kg} / \mathrm{m}^{3}\right.$ of concrete) } \\
& Cement & Water & Sand & Coarse aggregate \\
\hline 0.46 & 533 & 245 & 558 & 754 \\
0.53 & 463 & 246 & 597 & 754 \\
0.59 & 402 & 237 & 637 & 754 \\
0.70 & 346 & 242 & 645 & 754 \\
0.76 & 293 & 222 & 665 & 710 \\
\hline
\end{tabular}

at every three months but at those ages was plotted against the chloride content. The mean corrosion rate is the average of the measurements during a specific period of time on one single sample. A trend was drawn for each case, and the extrapolation of chloride content at 0.1 and $0.2 \mu \mathrm{A} / \mathrm{cm}^{2}$ gave the threshold ranges. The average of apparent resistivity $\left(\rho_{\text {mean }}\right)$ between the working electrode $(\mathrm{WE})$ and the internal $\mathrm{RE}$ (internal part) was obtained when chloride content was performed.

\section{Results}

Figure 3 shows the raw data of instantaneous $i_{\text {corr }}$ versus chloride content for each of the w/c ratios and times of curing tested in this work. As observed, some of the individual sets of $i_{\text {corr }}$ data cross around the depassivation zone at least once. This is understandable because of the natural exposure to the environment and the possible formation of corrosion layers and products. However, if finding a corrosion threshold, the information taken from the first time cross may be misleading since there is no a certain depassivation at that time. In fact, real depassivation occurs when data do not come back to the transition zone. On the other hand, chlorides follow an increasing behavior at any stage. This mean that it could be "two thresholds" for some sets of data, which is not correct.

The above situation brings the need to think in additional tools like $i_{\text {mean }}$ and $i_{\text {accum }}$ to obtain corrosion thresholds.

Figure 4 shows a representative plot of $i_{\text {mean }}$ as a function of chlorides for w/c of 0.76 and 0.70 (including information of the $3 \mathrm{tc}$ ). A similar trend was found in [5]. Similar data were obtained from the other $\mathrm{w} / \mathrm{c}$ ratios, and Table 2 summarizes the thresholds obtained for each one at $50 \mathrm{~m}$ from the seashore. Table 2 shows also the accumulated corrosion $\left(i_{\text {accum }}\right)$ defined as the sum of previous corrosion rates at each specific period of time. In general, the higher the w/c ratio, the lower the chloride threshold. The only exception was that of w/c of 0.46 which will be discussed below. Equations and regression coefficients $(R)$ were obtained and are shown in Table 3. Values of $R$ were similar in several cases to those of other investigations [5]. In general, the higher the w/c ratio the better the $R$ value.

\section{Discussion}

Three forms of obtaining the chloride threshold were done in this paper, and their results are presented in Table 2. The first one uses the instantaneous $i_{\text {corr }}$ to calculate the threshold 


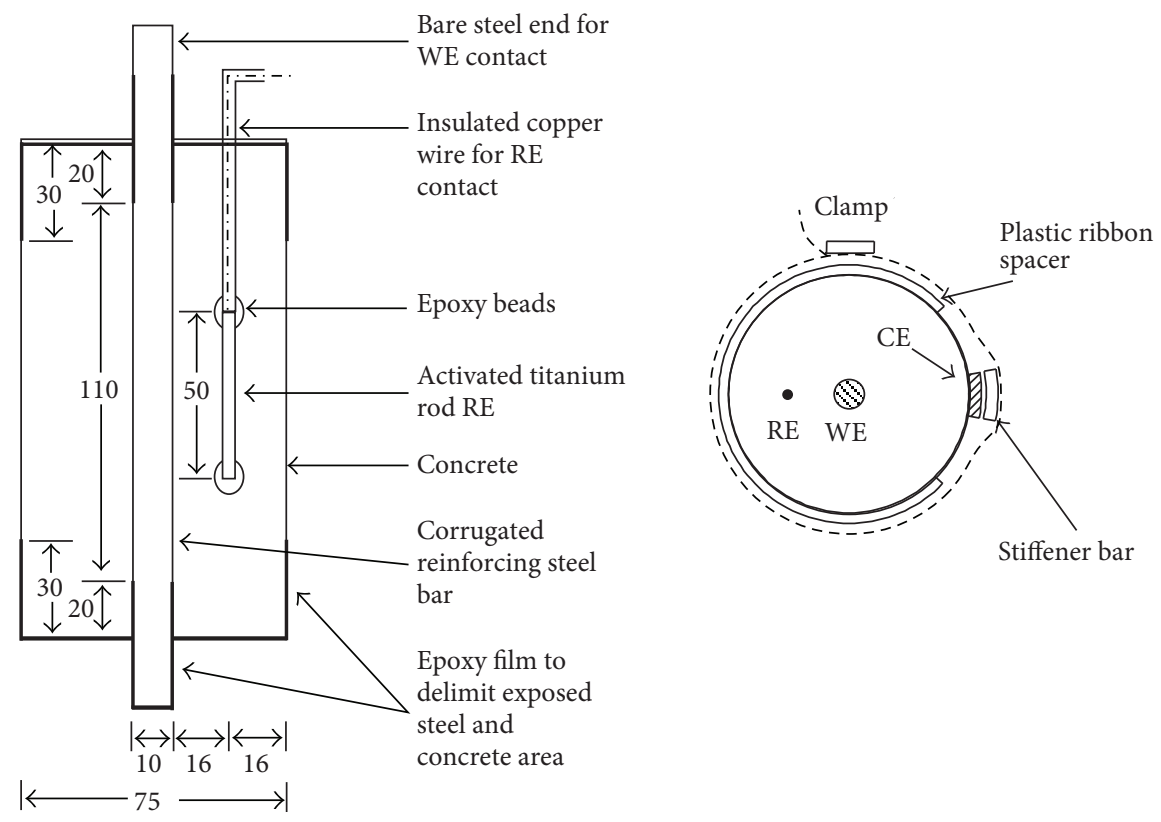

FIGURE 2: Schematic showing the cell configuration according to [10].

TABLE 2: Chloride threshold ranges and average at $50 \mathrm{~m}$ from the seashore for $\mathrm{w} / \mathrm{c}$ of 0.46 to 0.76 .

\begin{tabular}{|c|c|c|c|c|c|c|}
\hline $\mathrm{w} / \mathrm{c}$ & $\begin{array}{l}\text { Chloride threshold } \\
\text { range using } i_{\text {corr }}^{*} \\
\text { (\% per weight of } \\
\text { cement) }\end{array}$ & $\begin{array}{l}\text { Average of chloride } \\
\text { threshold using } \\
i_{\text {corr }}^{*}(\% \text { per weight } \\
\text { of cement) }\end{array}$ & $\begin{array}{l}\text { Chloride threshold } \\
\text { range using } i_{\text {mean }} \\
\text { (\% per weight of } \\
\text { cement) }\end{array}$ & $\begin{array}{l}\text { Average of chloride } \\
\text { threshold using } \\
i_{\text {mean }} \text { (\% per weight } \\
\text { of cement) }\end{array}$ & $\begin{array}{l}\text { Chloride threshold } \\
\text { range using } i_{\text {accum }} \\
\text { (\% per weight of } \\
\text { cement) }\end{array}$ & $\begin{array}{c}\text { Average of chloride } \\
\text { threshold using } \\
i_{\text {accum }} \text { (\% per } \\
\text { weight of cement) }\end{array}$ \\
\hline 0.46 & $0.38-0.54$ & 0.46 & $0.40-0.61$ & 0.50 & $0.26-0.33$ & 0.30 \\
\hline 0.53 & $0.55-0.79$ & 0.67 & $0.65-1.10$ & 0.87 & $0.39-0.53$ & 0.46 \\
\hline 0.59 & $0.52-0.68$ & 0.60 & $0.49-0.61$ & 0.55 & $0.56-0.73$ & 0.65 \\
\hline 0.70 & $0.35-0.47$ & 0.41 & $0.33-0.47$ & 0.40 & $0.37-0.50$ & 0.44 \\
\hline 0.76 & $0.35-0.49$ & 0.42 & $0.30-0.43$ & 0.76 & $0.38-0.50$ & 0.44 \\
\hline
\end{tabular}

Instantaneous $i_{\text {corr }}$ obtained at the moment when chlorides were measured.

TABLE 3: Equation and regression coefficient $(R)$ to calculate chloride threshold. Data using $i_{\text {mean }}$ and $i_{\text {accum }}$.

\begin{tabular}{|c|c|c|c|}
\hline & $\mathrm{w} / \mathrm{c}$ ratio & Equation & $R$ \\
\hline \multirow{5}{*}{$\begin{array}{l}\text { Extracted } \\
\text { with } i_{\text {mean }}\end{array}$} & 0.46 & $\log i_{\text {mean }}=-0.230+1.83 \log (\% \mathrm{Cl})$ & 0.69 \\
\hline & 0.53 & $\log i_{\text {mean }}=-0.742+1.49 \log (\% \mathrm{Cl})$ & 0.70 \\
\hline & 0.59 & $\log i_{\text {mean }}=-0.380+2.45 \log (\% \mathrm{Cl})$ & 0.90 \\
\hline & 0.70 & $\log i_{\text {mean }}=-0.030+2.18 \log (\% \mathrm{Cl})$ & 0.93 \\
\hline & 0.76 & $\log i_{\text {mean }}=-0.016+1.85 \log (\% \mathrm{Cl})$ & 0.92 \\
\hline \multirow{5}{*}{$\begin{array}{l}\text { Extracted } \\
\text { with } i_{\text {accum }}\end{array}$} & 0.46 & $\log i_{\text {accum }}=0.451+2.42 \log (\% \mathrm{Cl})$ & 0.70 \\
\hline & 0.53 & $\log i_{\text {accum }}=-0.061+2.32 \log (\% \mathrm{Cl})$ & 0.80 \\
\hline & 0.59 & $\log i_{\text {accum }}=0.042+3.41 \log (\% \mathrm{Cl})$ & 0.94 \\
\hline & 0.70 & $\log i_{\text {accum }}=0.282+3.12 \log (\% \mathrm{Cl})$ & 0.96 \\
\hline & 0.76 & $\log i_{\text {accum }}=0.205+2.98 \log (\% \mathrm{Cl})$ & 0.93 \\
\hline
\end{tabular}

when chlorides are measured. This form of calculating the threshold could be used only after being sure that $i_{\text {corr }}$ does not fluctuate a lot with time and around the depassivation
TABLE 4: Mean resistivity $(\mathrm{k} \Omega \cdot \mathrm{cm})$ at $50 \mathrm{~m}$ from the seashore for $\mathrm{w} / \mathrm{c}$ of 0.46 to 0.76 .

\begin{tabular}{lcc}
\hline & \multicolumn{2}{c}{ Mean resistivity $(\mathrm{k} \Omega \cdot \mathrm{cm})$} \\
$\mathrm{w} / \mathrm{c}$ & $50 \mathrm{~m}$ & \# of tests \\
\hline 0.46 & 30.56 & 6 \\
0.53 & 33.46 & 6 \\
0.59 & 34.54 & 5 \\
0.70 & 42.79 & 6 \\
0.76 & 43.37 & 6 \\
\hline
\end{tabular}

limit ( 8 of 15 cases in Figure 3 ). This is to say that it has reached a value that is increasing slowly with time and above the depassivation limit, as can be seen in several cases from Figure 3 but specifically in Figure 5 . However, this measuring method is not sufficient because it does not take into account the fluctuations of $i_{\text {corr }}$ during the early time of exposure. This is one of the reasons why other researchers [5] have 

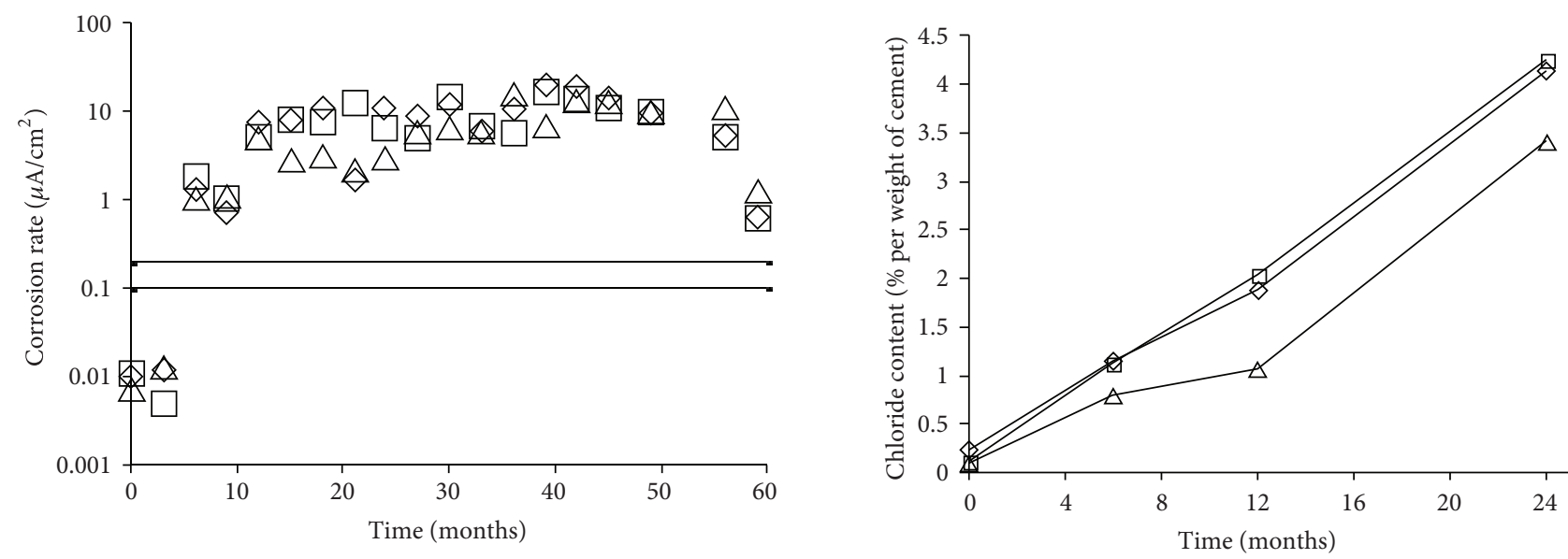
$\diamond 0.76-7$
$\square$ 0.76-3
$\triangle 0.76-1$

$$
\begin{array}{ll}
\triangleleft & 0.76-7 \\
\square & 0.76-3 \\
\triangle & 0.76-1
\end{array}
$$

(a)
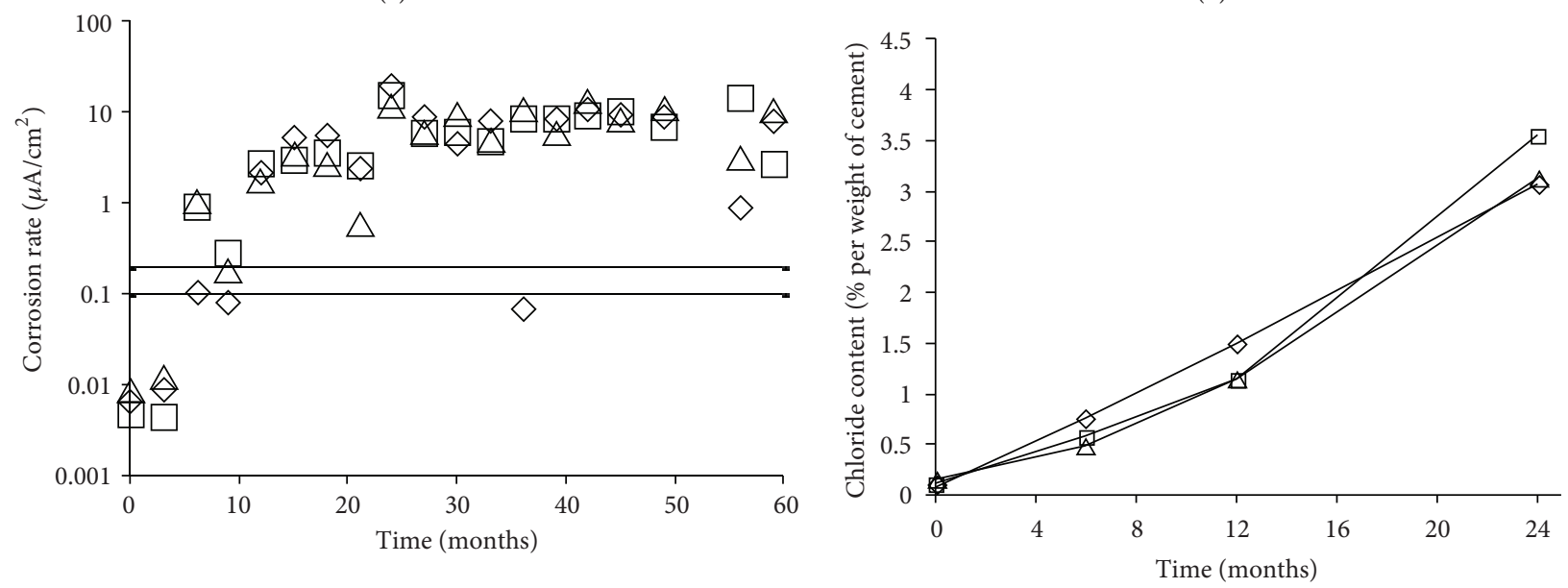
$\diamond 0.7-7$
$\square \quad 0.7-3$
$\triangle 0.7-1$

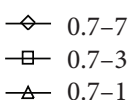

(c)
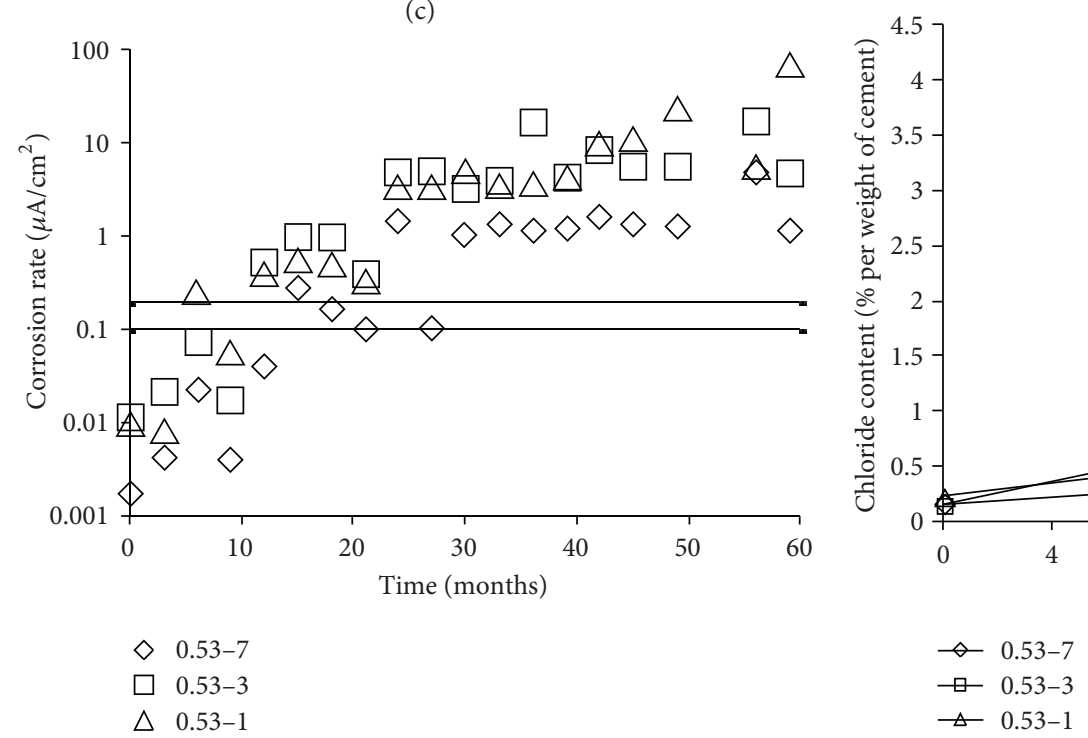

(d)
$\diamond 0.53-7$
$\square$ 0.53-3

$\triangle 0.53-1$

(e) 


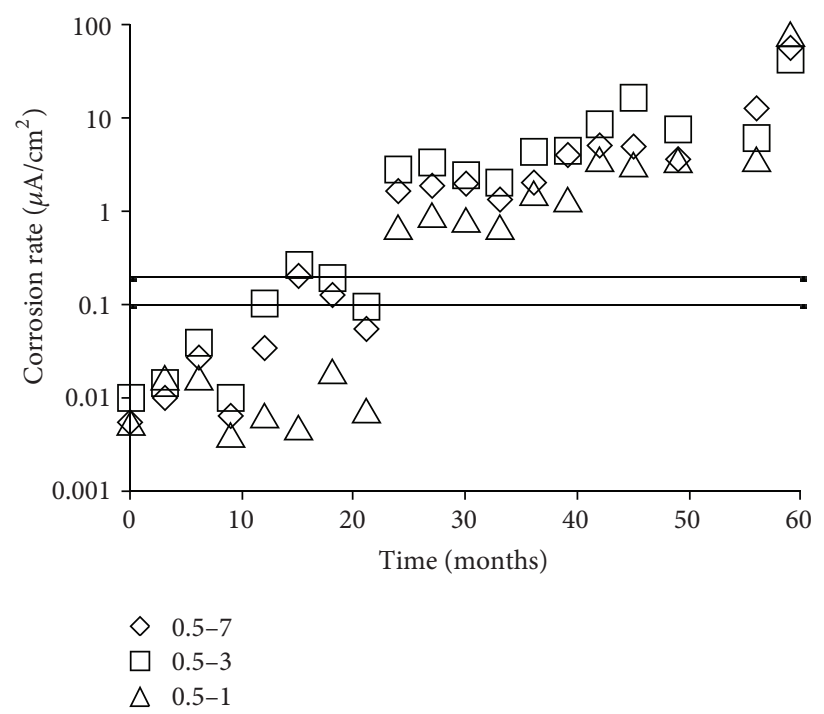

(g)

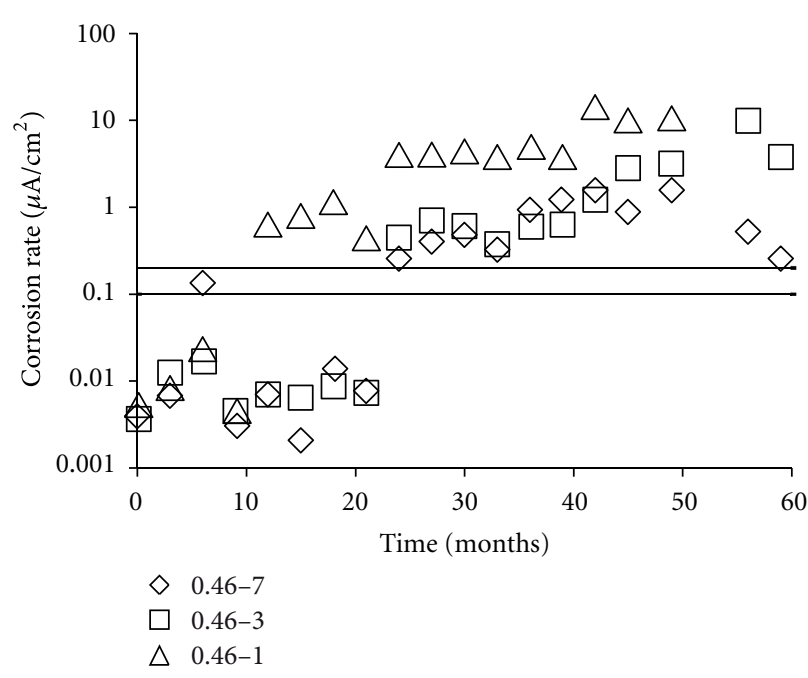

(i)

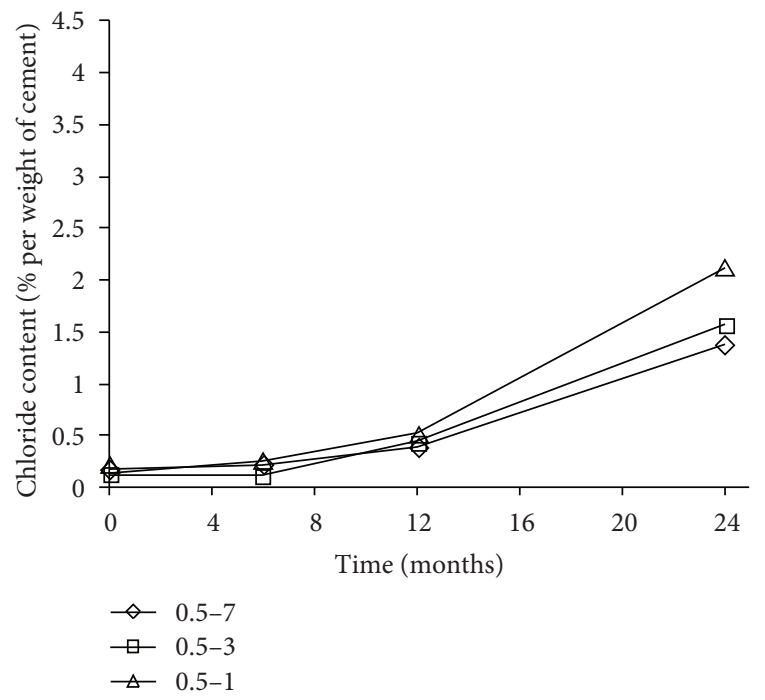

(h)

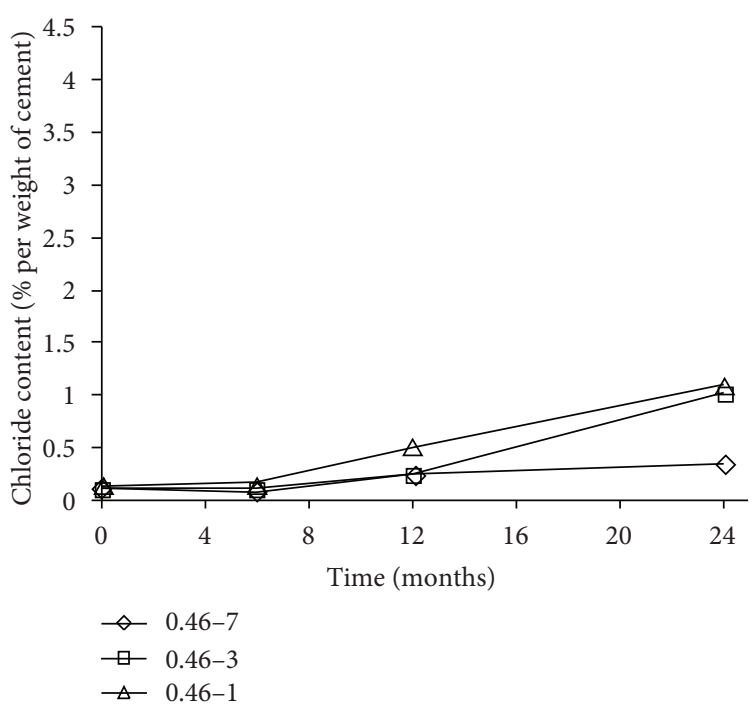

(j)

FIGURE 3: Instantaneous corrosion rate versus chloride content beside rebars for each of the w/c ratios and times of curing tested.

used the $i_{\text {mean }}$ as a more adequate parameter to calculate the chloride threshold. The form of calculating the threshold is possibly another cause of discrepancy among all the reported data in the literature. On the other hand, accumulative corrosion rate $\left(i_{\text {accum }}\right)$ could be a stronger parameter to obtain chloride threshold, since it takes into account and weighs several parameters involved in the electrochemical reaction. Therefore, $i_{\text {accum }}$ will show continuous variations of corrosion rate on the rebar. Table 2 shows clearly that the threshold could change significantly depending on the form of calculation. To compare the data of this paper with those of other authors, thresholds using $i_{\text {mean }}$ and $i_{\text {accum }}$ will be used for the discussion and conclusion.

4.1. Chloride Thresholds as a Function of Concrete Quality. Although w/c ratio was chosen as the most remarkable variable for comparison purposes, it has to be said that cement content and porosity have also an important role too [12]. Low w/c ratios can lead to low permeability concrete and to more durable concrete. During a exposure to a tropical marine climate, concrete is exposed to temperatures ranges between $23^{\circ} \mathrm{C}$ and $32^{\circ} \mathrm{C}$ as well as to relative humidities between $48 \%$ and $94 \%$. Depending on the concrete quality, moisture will have an influence on the internal apparent $\rho_{\text {mean }}$. For example, the internal parts of denser concretes will remain humid over a longer period than others despite being exposed to the same weather conditions (wet and dry cycles) and, therefore, should have a lower apparent $\rho_{\text {mean }}$, as seen in Table 4 . On the other hand, chlorides will reach the reinforcement easier in porous concretes that are subjected to wet and dry cycles. This situation together with a lower cement availability (higher porosity) to form 


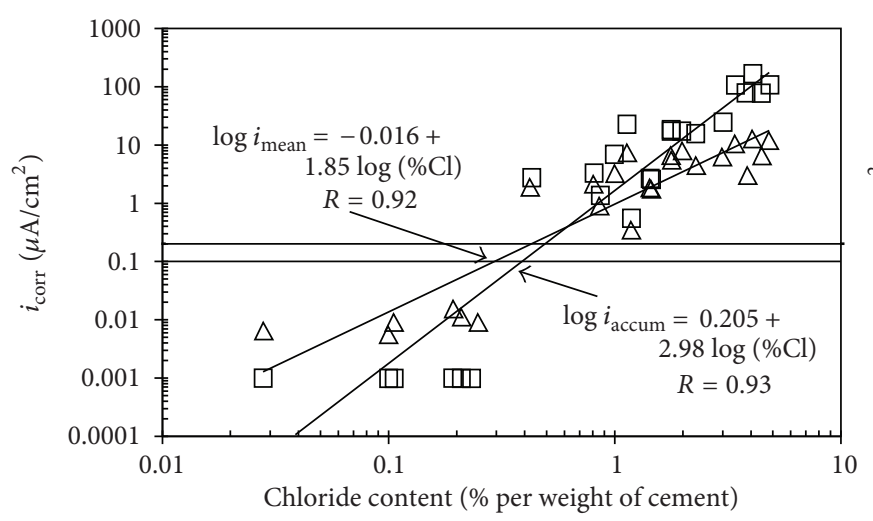

$\Delta 0.76 i_{\text {mean }}$

ㅁ $0.76 i_{\text {accum }}$

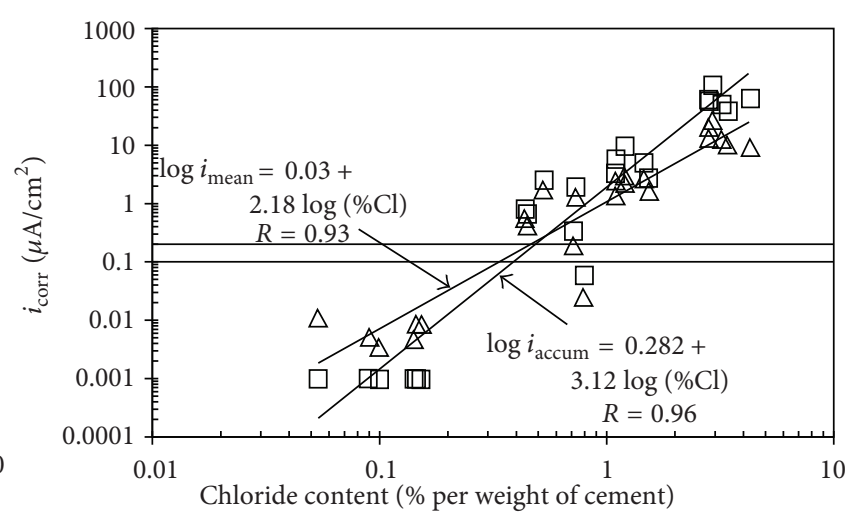

$\Delta 0.7 i_{\text {mean }}$

ㅁ $0.7 i_{\text {accum }}$

Figure 4: Chloride content versus $i_{\text {mean }}$ and $i_{\text {accum }}$ for specimens exposed at $50 \mathrm{~m}$ from the seashore and w/c ratio of (a) 0.76 and (b) 0.70 .

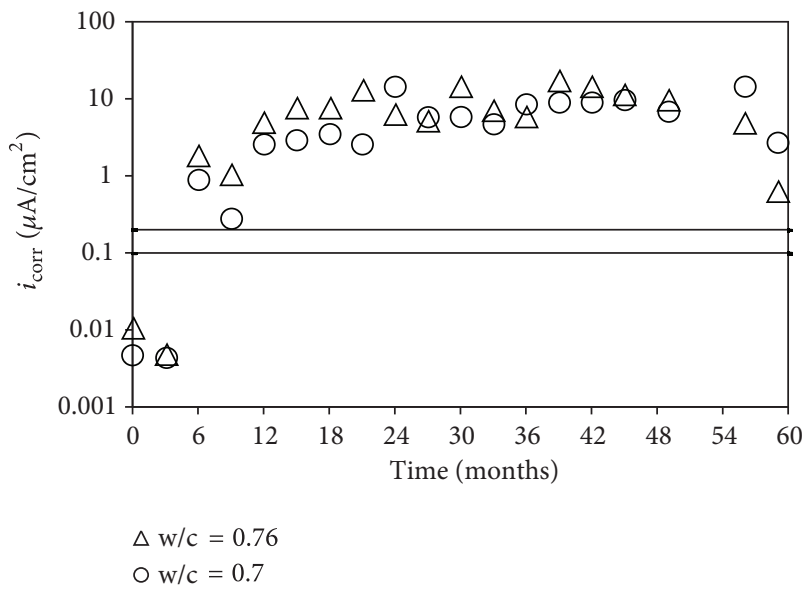

FIGURE 5: Instantaneous corrosion rate of the rebar $(\mathrm{w} / \mathrm{c}=0.70$ and $0.76,3$ days of curing, $50 \mathrm{~m})$.

chloroaluminates in high $\mathrm{w} / \mathrm{c}$ ratios leads to have higher chloride thresholds for low w/c ratios than for higher ones. This is also due to the fact that in saturated environments, as would be the case of the internal parts of denser concretes, where water evaporates slower than in others, there is a lack of oxygen to promote the cathodic reaction. Therefore, chloride accumulates close to the rebar until oxygen is sufficiently available to catalyze the corrosion reaction. These are some of the possible reasons why the higher the $\mathrm{w} / \mathrm{c}$ ratio the lower the threshold in front of the seashore $(50 \mathrm{~m})$ as seen in Table 2. On the other hand, the only exception on the trend of chloride threshold in function of concrete quality was that of the w/c ratio of 0.46 . The concretes were set following the traditions of this region for handmade concretes. This is to say that no super plasticizers were used. On the other hand, the sieve analysis was performed, and excess in fines was found and used as the local costumes. In this way, there is a possibility that $\mathrm{w} / \mathrm{c}$ ratio of $0.46 \mathrm{did}$ not adequately cure, so there is a chance to have a mixture that could be more permeable than the previous one. This situation leads to a misleading result which is not representative of the expected tendencies.

4.2. Comparison between $i_{\text {mean }}$ and $i_{\text {accum }}$. Figure 6 shows $i_{\text {accum }}$ and chloride concentration versus time for a selected and specific w/c ratio of 0.70 at three different curing times. The specific points of the $i_{\text {accum }}$ plot do not represent a particular measurement but just the time at which chlorides were obtained. The distance between them represents also a slope change on the behavior of $i_{\text {accum. }}$. As observed from this Figure, there is a common change of $i_{\text {accum }}$ slope after 6 months of exposure. This "new" slope could be related with the rebar depassivation and especially with the beginning of this stage.

On the other hand, Figure 4 shows that a similar but not equal threshold was apparently found with both, $i_{\text {mean }}$ and $i_{\text {accum }}$. However, the intersection between both tendencies could provide important information about the beginning of depassivation since it is related with a possible change of $i_{\text {accum }}$ slope, as observed in Figure 6. From the intersection point, $i_{\text {accum }}$ becomes more accurate because it takes into account not only depassivation and the temporal and instantaneous electrochemical and environmental reactions $\left(i_{\text {mean }}\right)$ but also several others on the rebar. That is, the reason why a range of chloride threshold provided by $i_{\text {accum }}$ would be more accurate than the others. On the other hand, and as a conservative point of view in civil engineering, the lower value of this range must be taken as the real chloride threshold, this is, the initial point of the "new" slope of $i_{\text {accum }}$ (Figure 6). From the same Figure 6, other changes of slopes during the service life of the sample may be related to other several instantaneous and accumulative chemical or electrochemical reactions. However, more information is needed to demonstrate this.

According to the use of these tools, $i_{\text {mean }}$ represents a very accurate tool to obtain chloride thresholds as has been stated by other researchers [5]. However, $i_{\text {accum }}$ is a tool that takes into account several of the parameters involved in the electrochemical reactions and environment. This means that several 


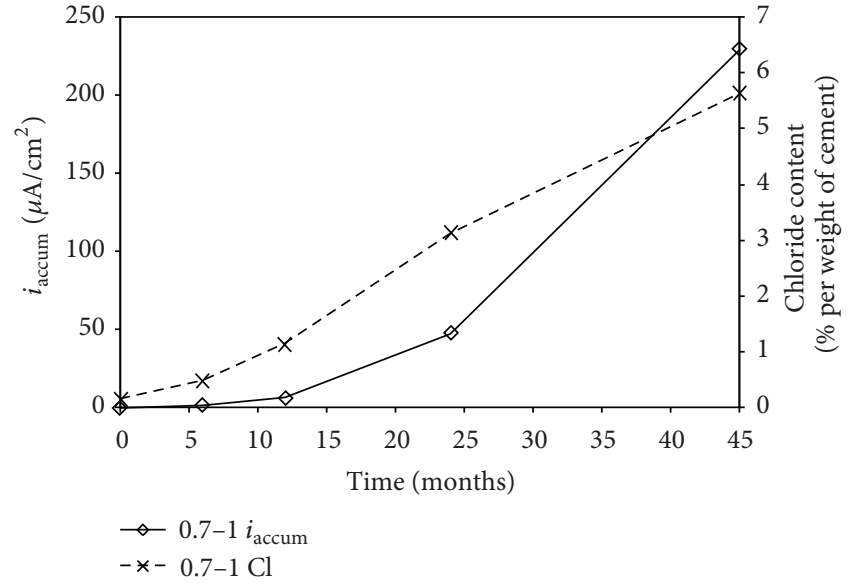

(a)

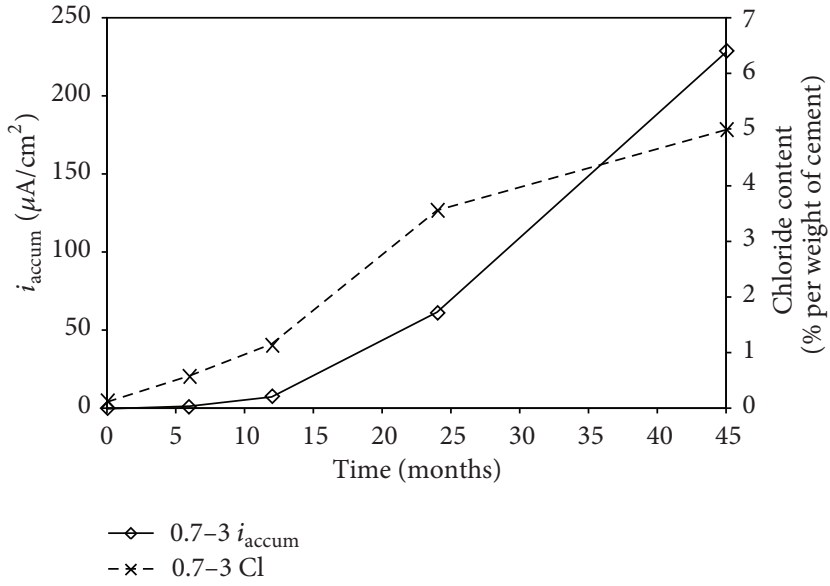

(b)

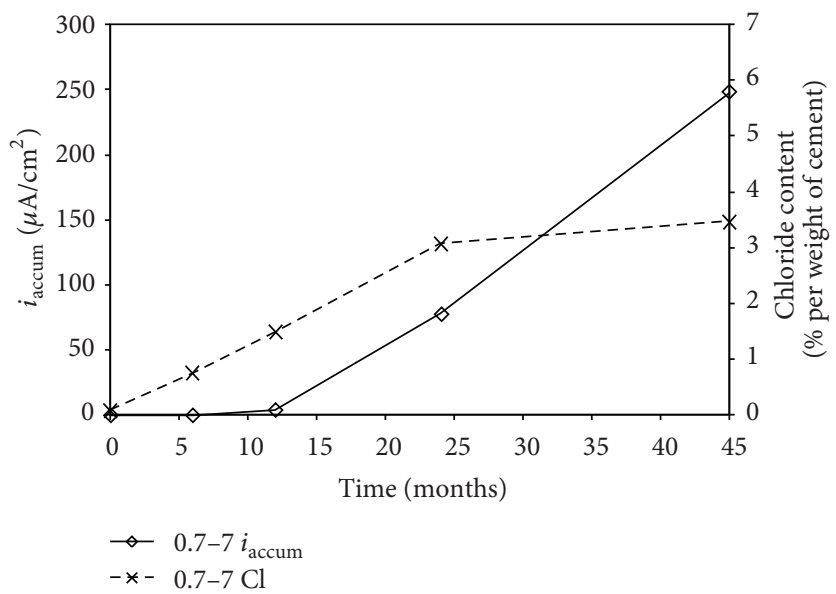

(c)

FIGURE 6: $i_{\text {accum }}$ and chloride concentration versus time for a selected and specific w/c ratio of 0.70 at three different curing times (a) 1 day, (b) 3 days, and (c) 7 days.

processes take place during the service life of reinforced concrete (action of the environment, alkali/silica reaction, action of sulphates, corrosion reactions, carbonation, phase transformations, etc.). Because of many known reasons, all of them may affect the acceleration or disacceleration of the rebar corrosion rate. An instantaneous $i_{\text {corr }}$ will show the momentaneous action of any of these processes while the mean $i_{\text {corr }}$ an average of them. The trend of $i_{\text {accum }}$ will show slopes with time that will the reader understand not only the total corrosion rate but also the changes in intensities of the whole reactions because of all of those processes. For this reason and from the change of slope, $i_{\text {accum }}$ becomes a better parameter to obtain and predict chloride thresholds for this specific case.

4.3. Comparison with Data from Other Authors. Chloride thresholds $\left(i_{\text {mean }}\right)$ of this investigation were in a range of $0.3 \%$ to $1.1 \%$, and those of other authors using standardized mortars [5] were between $1.24 \%$ and $3.08 \%$. Then, chloride thresholds obtained here are in the same order of magnitude of other authors but under different conditions to those reported until now. The tool of $i_{\text {accum }}$ was important for the results of this paper. However, as stated by other authors [13], there is still a strong need for practice-related methods.

\section{Conclusions}

Conclusions of this paper apply for the tested materials and exposure conditions. Extrapolation to other circumstances must be performed carefully.

After a number of years of exposure to a tropical marine environment, the chloride threshold for portland cement reinforced concrete showed to be in dependence of concrete quality and, possibly, of the criteria to obtain it. For the tropical marine environment of Yucatan, $i_{\text {accum }}$ is a new and better tool to determine chloride threshold. A summary of the conclusions is as follows.

(A) Three tools to determine chloride threshold for corrosion onset of reinforced concrete in the tropical marine environment of Yucatan were discussed. The 
$i_{\text {accum }}$ constituted a more accurate tool to determine the chloride threshold for specific materials and circumstances of the natural environment of Yucatán.

(B) According to point of view of civil engineering, a conservative criterion for considering a chloride threshold must take into account the lower value of the found range.

(C) Chloride threshold fluctuates between $0.26 \%$ and $0.73 \%$ for w/c from 0.46 to 0.76 . Our conservative value will be then $0.26 \%$.

(D) In front of the sea (50 $\mathrm{m}$ from the seashore), the lower the $\mathrm{w} / \mathrm{c}$ ratio the higher the chloride threshold.

\section{Acknowledgments}

The authors wish to acknowledge CINVESTAV-IPN Unidad Mérida, CONACYT for partial support, and to Dr. A. Sagüés for his advice during the experiments design and cooperation.

\section{References}

[1] H. Yu, K. T. K. Chiang, and L. Yang, "Threshold chloride level and characteristics of reinforcement corrosion initiation in simulated concrete pore solutions," Construction and Building Materials, vol. 26, no. 1, pp. 723-729, 2011.

[2] K. H. Petterson, "Corrosion threshold value and corrosion rate in reinforced concrete," C. B. I. Report 2:92, Swedish Cement and Concrete Research Institute, Stockholm, Sweden, 1992.

[3] S. E. Hussain, Rasheeduzzafar, A. Al-Musallam, and A. S. AlGahtani, "Factors affecting threshold chloride for reinforcement corrosion in concrete," Cement and Concrete Research, vol. 25, no. 7, pp. 1543-1555, 1995.

[4] M. Funahashi, "Predicting corrosion-free service life of a concrete structure in a chloride environment," ACI Materials Journal, vol. 87, no. 6, pp. 581-587, 1990.

[5] C. Alonso, C. Andrade, M. Castellote, and P. Castro, "Chloride threshold values to depassivate reinforcing bars embedded in a standardized OPC mortar," Cement and Concrete Research, vol. 30, no. 7, pp. 1047-1055, 2000.

[6] C. L. Page, "Initiation of chloride-induced corrosion of steel in concrete: role of the interfacial zone," Materials and Corrosion, vol. 60, no. 8, pp. 586-592, 2009.

[7] G. K. Glass and N. R. Buenfeld, "Chloride threshold levels for corrosion induced deterioration of steel in concrete," in Proceedings International Workshop, Saint Remy Les Cherreuse, France, October 1995.

[8] P. Castro and L. Maldonado, "Initial efforts to evaluate the corrosion problems in the infrastructure of Mexican Souteasth coastal zones," in Innovative Ideas For Controlling the Decaying Infrastructure, V. Chaker, Ed., pp. 119-136, NACE International, 1995.

[9] P. Castro, A. A. Sagüés, E. I. Moreno, L. Maldonado, and J. Genescá, "Characterization of activated titanium solid reference electrodes for corrosion testing of steel in concrete," Corrosion, vol. 52, no. 8, pp. 609-617, 1996.

[10] M. A. Pech-Canul, A. A. Sagüés, and P. Castro, "Influence of counter electrode positioning on solution resistance in impedance measurements of reinforced concrete," Corrosion, vol. 54, no. 8, pp. 663-667, 1998.
[11] J. A. Gonzalez, S. Algaba, and C. Andrade, "Corrosion of reinforcing bars in carbonated concrete," British Corrosion Journal, vol. 15, no. 3, pp. 135-139, 1980.

[12] M. S. Sumanasooriya and N. Neithalath, "Pore structure features of pervious concretes proportioned for desired porosities and their performance prediction," Cement and Concrete Composites, vol. 33, no. 8, pp. 778-787, 2011.

[13] U. Angst, B. Elsener, C. K. Larsen, and Ø. Vennesland, "Critical chloride content in reinforced concrete-a review," Cement and Concrete Research, vol. 39, no. 12, pp. 1122-1138, 2009. 

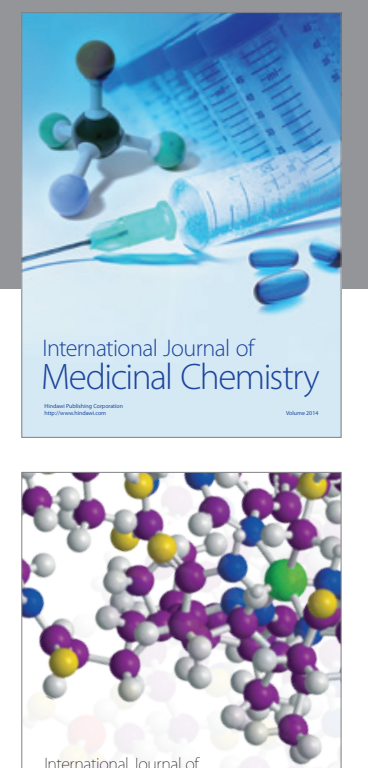

\section{Carbohydrate} Chemistry

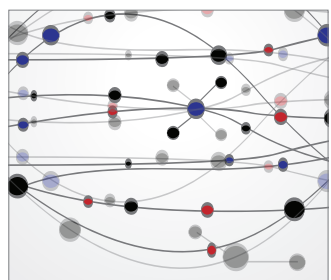

The Scientific World Journal
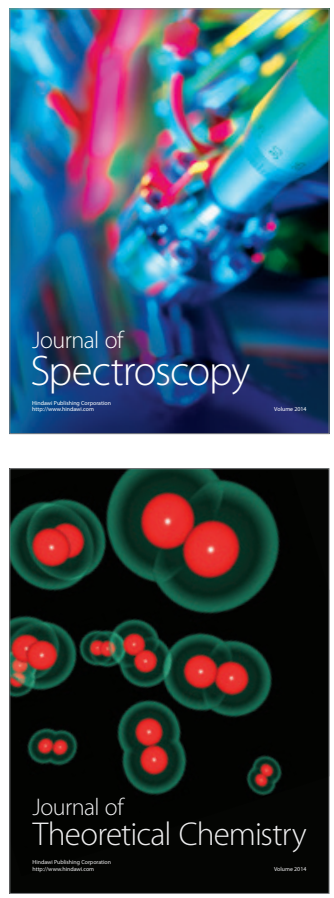
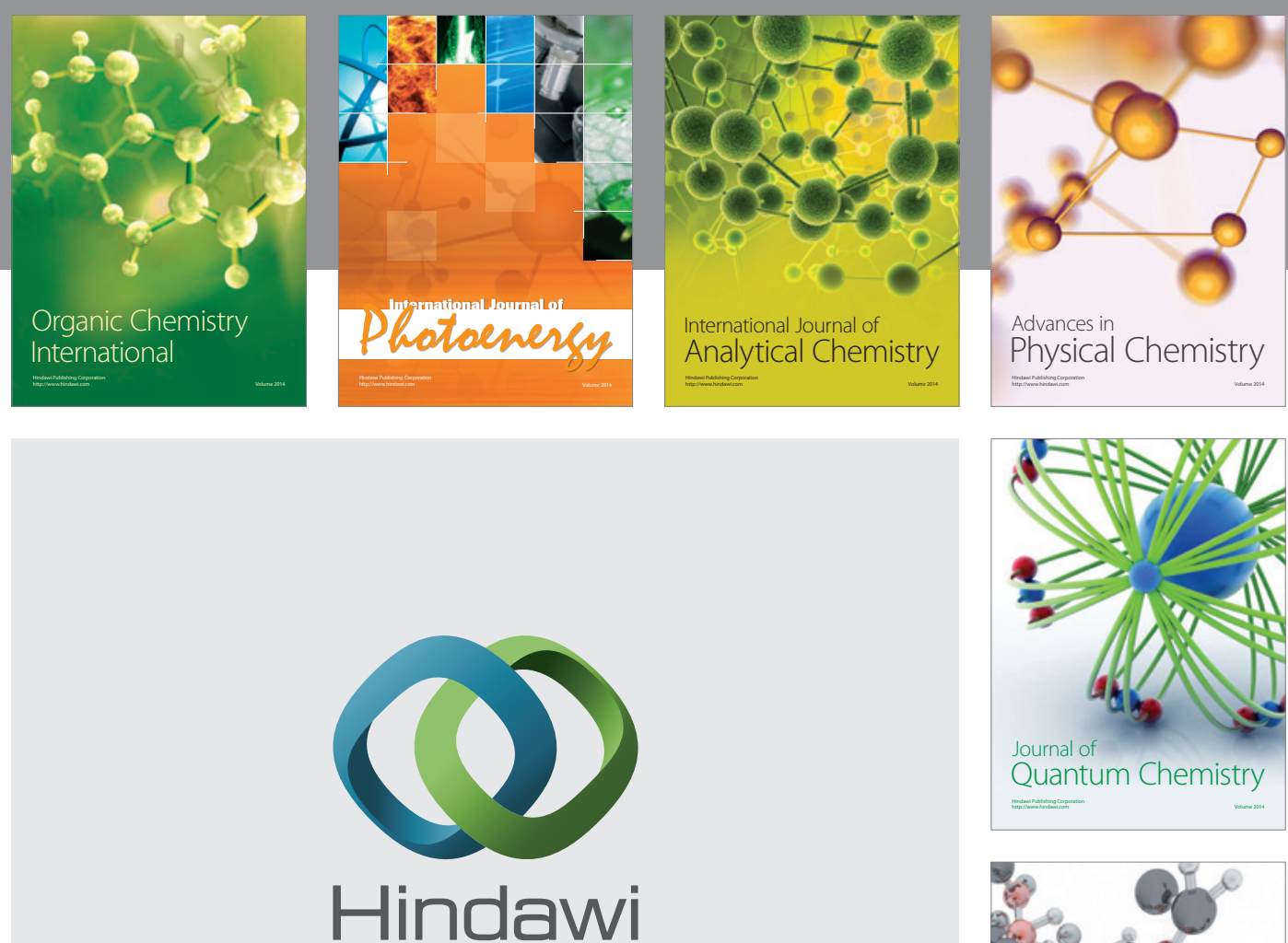

Submit your manuscripts at

http://www.hindawi.com

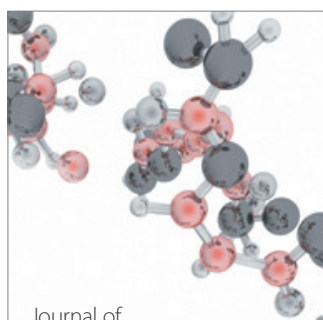

Analytical Methods

in Chemistry

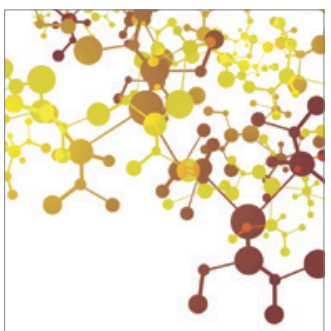

Journal of

Applied Chemistry

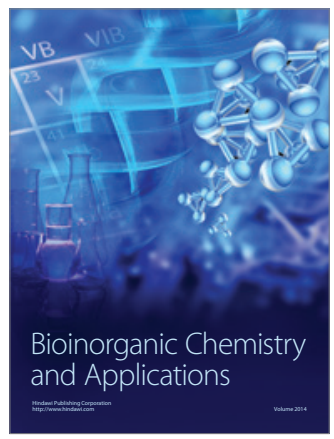

Inorganic Chemistry
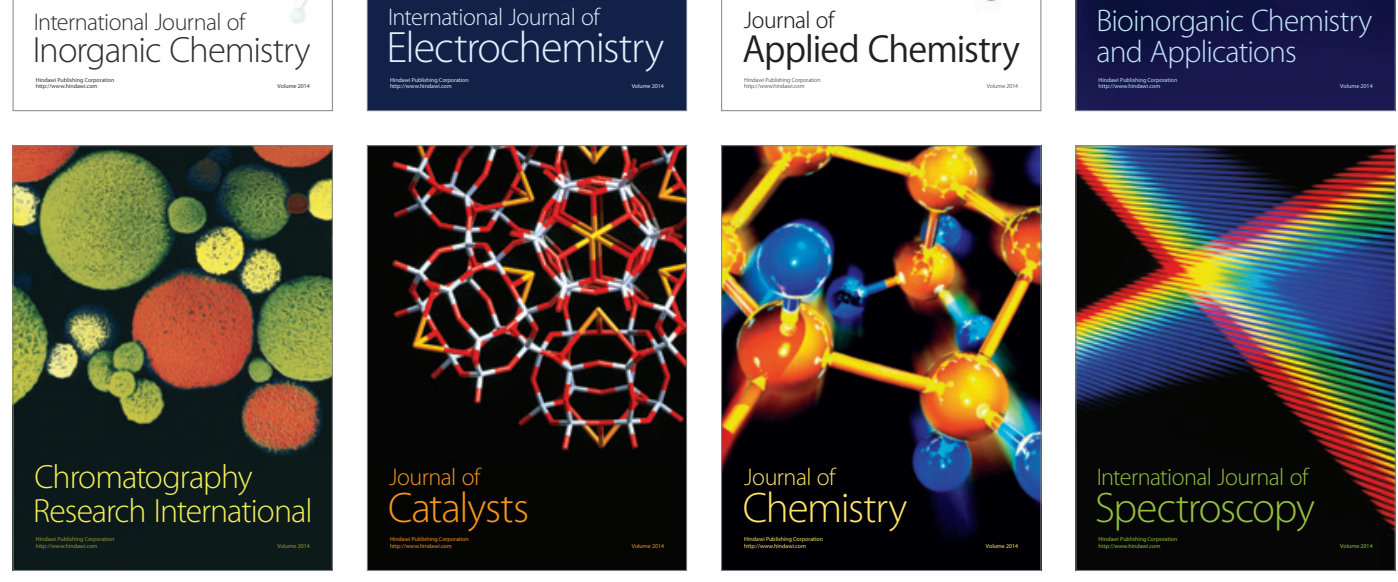